Research Article

\title{
Pharmacognostic Study and Antioxidant Activity of Mundar (Garcinia forbesii King.) leaves from Banua Botanical Gardens of South Kalimantan
}

Sutomo ${ }^{1,2}$ *
Dina Noor Kamali ${ }^{1}$
Arnida 10
Normaidah 10
Agung Sriyono ${ }^{3}$
1Department of Pharmacy, Universitas
Lambung Mangkurat, Banjarbaru,
South Kalimantan, Indonesia
2Center for Study of Natural Medicine,
Universitas Lambung Mangkurat,
Banjarbaru, South Kalimantan,
Indonesia
3Badan Penelitian dan Pengembangan
Kebun Raya Banua Kalimantan Selatan,
Banjarbaru, South Kalimantan,
Indonesia
*email: sutomo01@ulm.ac.id
Keywords:
Antioxidant
Garcinia forbesii King.
Leaves
Mundar
Pharmacognostic study

\begin{abstract}
Mundar (Garcinia forbesii King.) is a plant from South Kalimantan. This plant has chemical contents that have potential as medicine. The purpose of this study is to provide a pharmacognostic picture of a specific, nonspecific and determine the antioxidant activity of $G$. forbesii leaves. Specific parameters include organoleptic, microscopic testing, thin-layer chromatography profiles, and phytochemical screening. Nonspecific parameters include total ash content, acid insoluble ash content, drying loss, water-soluble extract content, and ethanol-soluble extract content. Antioxidant activity was determined by the $\mathrm{DPPH}$ method based on $\mathrm{IC}_{50}$ values. Specific parameter test results are green powder, characteristic odor, and sour taste. Microscopic tests showed stomata, upper epidermis, lower epidermis, cell walls, xylem, phloem, palisade tissue, spongy tissue, and cuticles. Garcinia forbesii leaves contain alkaloids, flavonoids, phenols, tannins, and steroids. The TLC profile showed good separation of polar eluents, and yellow spots appeared after spraying DPPH reagents. The non-specific parameter test is the total ash content of $6.52 \pm 0.1 \%$; acid insoluble ash content $1.06 \pm 0.08 \%$; drying shrinkage $6.43 \pm 0.38 \%$; watersoluble extracts $34.3 \pm 0.3 \%$; and ethanol-soluble extracts $23.47 \pm 0.35 \%$. Ethanol extract of $G$. forbesii leaves has antioxidant activity with $\mathrm{IC}_{50}$ of 65.7 ppm. Pharmacognostic study fulfills the requirements, and G. forbesii leaves extract has strong antioxidant activity.
\end{abstract}

Received: July $16^{\text {th }}, 2020$

Accepted: October 30th, 2020

Published: November 30th, 2020

(C) 2020 Sutomo, Dina Noor Kamali, Arnida, Normaidah, Agung Sriyono. Published by Institute for Research and Community Services Universitas Muhammadiyah Palangkaraya. This is an Open Access article under the CC-BYSA License (http://creativecommons.org/licenses/by-sa/4.0/). DOI: https://doi.org/10.33084/bjop.v3i4.1541

\section{INTRODUCTION}

Indonesia has a diversity of natural materials, most of which have medicinal properties, one of which is the mundar (Garcinia forbesii King.) (Figure 1A). Garcinia forbesii is an original plant from South Kalimantan. The G. forbesii leaves (Figure 1B) are used by the people of Bangun Jaya, South Sumatra, as traditional medicine for constipation treatment. Many studies about G. forbesii plant activities from the stem bark and fruit peels. The $G$. forbesii stem bark contains rubraxanthone that has antimicrobial activities (Alen et al., 2008). The fruit peels were extracted with ethanol $30 \%$ and $70 \%$ have antioxidant studied on the method of 1,1-diphenyl-2picrylhidrazyl (DPPH) with $\mathrm{IC}_{50}$ value more than 500 ppm (Muthia et al., 2019) and the ethyl acetate fraction of the fruit peels of ethanol $70 \%$ extract have antioxidant activity with $\mathrm{IC}_{50}$ value 72.386 ppm (Muthia et al., 2018). Besides that, the fruit peels ethanol extract shows the antioxidant activity on the method of ferric reducing antioxidant power (FRAP) (Dewi, 2018) as well as water 
extract with DPPH method (Andarini et al., 2018). However, the part that is often scrutinized is fruit skin that is more difficult to obtain because it is seasonal, and the study of its leaves was reported just from the fraction of $n$-hexane. It has also been investigated as having antibacterial properties against Escherichia coli and Staphylococcus aureus (Larasati, 2017; Lim, 2012). Our research is the first study of the antioxidant activity of $G$. forbesii leaves.

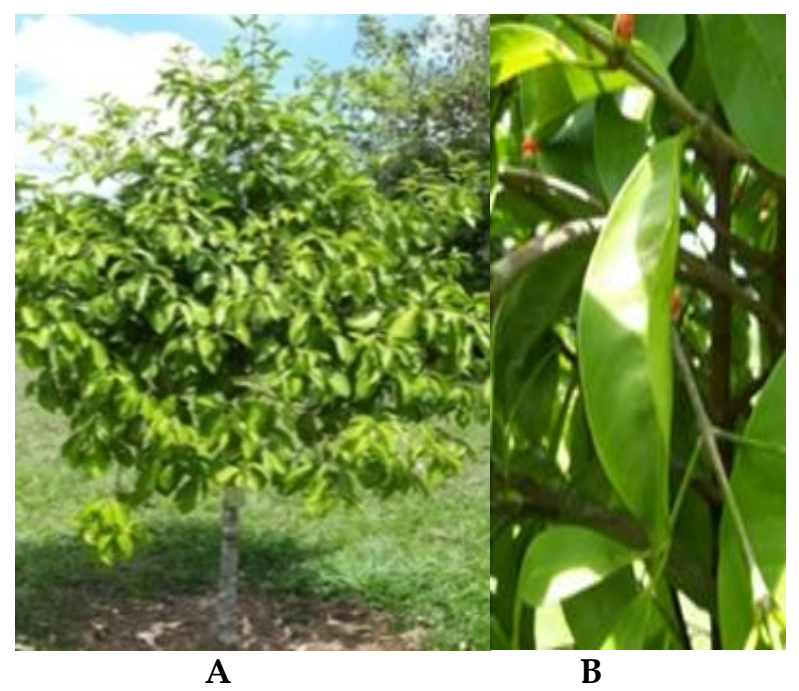

Figure 1. Garcinia forbesii whole plant (A) and leaves (B)

All the research was reported not contain the whole of standardization. This causes the need for quality testing and the quality of the materials used to ensure safety and efficacy. The pharmacognostic study is the basis and part of the plant standardization process in a simple way. This test is useful to support identification and determine plant material's efficacy and safety (Sapna et al., 2008). The study of antioxidant activity is useful to provide preliminary data in the development of natural materials to increase the feasibility of using plants as herbal medicines. Antioxidant activity can be determined from the $\mathrm{IC}_{50}$ value by the DPPH method (Hadadi et al., 2020). The DPPH method is a simple method through radical reduction with accurate, reliable, and relatively short time (Kedare \& Singh, 2011). Based on the description above, researchers are interested in conducting the pharmacognostic study and antioxidant activity of the $G$. forbesii leaves. The pharmacognostic study can provide an identification and safety guarantee of the G. forbesii leaves. The study of antioxidant activity can support the discovery of antioxidant sources in the treatment of various diseases. The results of these studies are expected to provide information on G. forbesii leaves as raw material for medicine and can be used as a scientific basis for further research.

\section{MATERIALS AND METHODS}

\section{Tools and materials}

The tools used in this study were furnaces (Ney-Vulcan D-550), UV lamps 254 and $366 \mathrm{~nm}$, drying cabinet, maceration chamber, microscope, oven (Vinco), UV-Vis spectrophotometer (Genesys 10 v2. 100 2H3K297003), rotary evaporator (Heidolph Laborate 40004000 Efficient), analytical scales (Pioneers), and water bath (Memmert). The materials used are distilled water, acetic acid, hydrochloric acid, sulfuric acid, $\mathrm{FeCl}_{3}$, DPPH, ethanol 96\%, ethyl acetate (pro analysis), gelatin, potassium hydroxide, chloroform, quercetin, $\mathrm{Mg}$ powder, methanol (pro analysis), $n$-hexane (pro analysis), silica gel $\mathrm{GF}_{254}$, Dragendorff's reagent, Liebermann-Burchard reagent, and Mayer's reagent.

\section{Material collection, simplicia processing, and extracting}

The G. forbesii leaves were collected from Kebun Raya Banua Kalimantan Selatan, Banjarbaru, South Kalimantan. The G. forbesii leaves powder is made by wet sorting, washing, chopping, dry sorting, and refining. As much as $200 \mathrm{~g}$ of $\mathrm{G}$. forbesii leaves powder was extracted by maceration method using $96 \%$ ethanol solvent. Extraction was carried out for $3 \times 24$ hours with stirring every eight hours and solvent replacement every 24 hours. The liquid extract obtained was filtered and evaporated with a rotary evaporator and then thickened 
on a water bath at a temperature of $50^{\circ} \mathrm{C}$ until a thick extract with constant weight was obtained.

\section{Pharmacognostic study}

The Pharmacognostic study includes specific parameters and nonspecific parameters. Specific parameters consist of organoleptic study, microscopic study, phytochemical screening on simplicia powders and extracts, and TLC profiles. The nonspecific parameters include total ash content, acid insoluble ash content, shrinkage of drying, water-soluble extract, and ethanol-soluble extract.

\section{Determination of antioxidant activity}

The G. forbesii leaves ethanol extract's antioxidant activity was determined using the DPPH method based on $\mathrm{IC}_{50}$ values. Determination of antioxidant activity is done by determining the maximum wavelength of DPPH, operating time, determining the $\mathrm{IC}_{50}$ value of quercetin as a reference and ethanol extract.

\section{RESULTS AND DISCUSSION}

\section{Simplicia processing and extracting}

The G. forbesii leaves are taken from Kebun Raya Banua Kalimantan Selatan, Banjarbaru, South Kalimantan. Fresh leaves as much as $1.55 \mathrm{~kg}$ and after processing obtained dry simplicia (Figure 2A) as much as $458 \mathrm{~g}$. From $200 \mathrm{~g}$ of simplicia extracted with $96 \%$ ethanol, 47.28 $\mathrm{g}(23.64 \%)$ of thick extract (Figure 2B) was obtained.
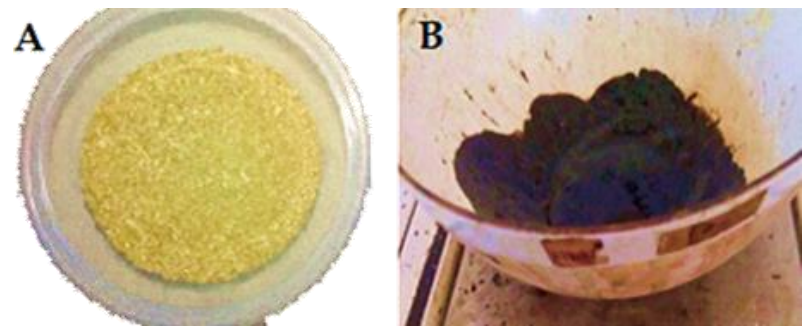

Figure 2. Simplicia (A) and extract (B) of G. forbesii leaves

\section{Plant determination}

The G. forbesii plant's determination was carried out at the Indonesian Institute of Sciences (LIPI), Bogor, West Java.
Determination serves as a confirmation that the plants used in this study are the correct samples so that the test results are specific and right on target (Altemimi et al., 2017). Based on the statement of the results of the determination carried out at LIPI Bogor with letter number B-416/IPH.3/KS/III/2019, family and species data were obtained from the sample. The sample was stated to belong to Clusiaceae's family and was a species of Garcinia forbesii King.

\section{Pharmacognostic study}

The organoleptic study of the G. forbesii leaves simplicia shows green powder, sour taste, and characteristic odor of $G$. forbesii leaves. The green color is faded compared to fresh leaves because it has undergone drying so that the chlorophyll content in this simplicia is reduced. Sour taste is caused by the content of phenolic compounds (Kabera et al., 2014). The pungent smell of simplicia of G. forbesii leaves, which is quite strong, is possible from the essential oil content.

The microscopic study was carried out using a light microscope on the longitudinal and transverse crosssection of $G$. forbesii leaves with a magnification of $10 \times 10$. This examination aims to see the anatomy and characteristics of the sample. The epidermal cells in the $G$. forbesii leaves' longitudinal cross-section are known to have curved and zig-zag cell wall forms. Stomata on the G. forbesii leaves are found in adaxial and abaxial with the parasitic type. Garcinia forbesii leaves' cross-section showed upper epidermis, cuticles, palisade tissue, spongy tissue, transport bundles such as xylem and phloem, and lower epidermis.

Based on phytochemical screening, the simplicia powder and the G. forbesii leaves extract contained the same compounds, such as alkaloids, flavonoids, tannins, steroids, and phenolics. These results indicate that the compound content in the simplex powder did not change after the extraction process. This can show the 
consistency of the compounds contained after processing, as presented in Table I.

Table I. Phytochemical screening test results for G. forbesii leaves

\begin{tabular}{|c|c|c|c|c|}
\hline \multirow{2}{*}{ Compounds } & \multirow{2}{*}{ Reagent } & \multicolumn{2}{|c|}{ Result } & \multirow{2}{*}{ Note } \\
\hline & & Powder & Extract & \\
\hline \multirow[t]{2}{*}{ Alkaloid } & Dragendorff's & $\begin{array}{l}\text { Red } \\
\text { sediment }\end{array}$ & $\begin{array}{l}\text { Dark red } \\
\text { sediment }\end{array}$ & + \\
\hline & Mayer's & $\begin{array}{l}\text { Yellowish } \\
\text { white } \\
\text { sediment }\end{array}$ & $\begin{array}{l}\text { Brownish } \\
\text { white } \\
\text { sediment }\end{array}$ & + \\
\hline Flavonoid & $\begin{array}{l}\text { Mg powder+ } \\
\mathrm{H}_{2} \mathrm{SO}_{4} \\
\text { concentrated }\end{array}$ & $\begin{array}{l}\text { Reddish } \\
\text { orange }\end{array}$ & Red & + \\
\hline Tannin & Gelatin 1\% & $\begin{array}{l}\text { White } \\
\text { sediment }\end{array}$ & $\begin{array}{l}\text { White } \\
\text { Sediment }\end{array}$ & + \\
\hline Saponin & $\begin{array}{l}\text { Shake } \\
\text { vigorously with } \\
\text { water }\end{array}$ & $\begin{array}{l}\text { Unstable } \\
\text { foam }\end{array}$ & $\begin{array}{l}\text { Unstable } \\
\text { foam }\end{array}$ & - \\
\hline Steroid & $\begin{array}{l}\text { Liberman- } \\
\text { Burchard }\end{array}$ & $\begin{array}{l}\text { Bluish } \\
\text { green }\end{array}$ & $\begin{array}{l}\text { Dark } \\
\text { blue }\end{array}$ & + \\
\hline Phenol & $\mathrm{FeCl}_{3} 1 \%$ & Black & Black & + \\
\hline
\end{tabular}

On observing the chromatogram profile, it is known that there is a good separation in the eluent $n$-hexane-ethyl acetate $(8: 2) \mathrm{v} / \mathrm{v}$ and $n$-hexane-ethyl acetate $(6: 4) \mathrm{v} / \mathrm{v}$. The chromatograms on the chloroform-methanol (9.5 : 0.5) v/v show one spot on the TLC plate's upper limit. That is because the compounds in the sample have low polarity so that the compound spots are still not separated in the eluent. The spraying TLC by elution of all three types of eluents with DPPH reagents shows that yellow spots on a purple background indicate the compound has antioxidant activity. Yellow spots appeared with Rf values of 0.27 and 0.45 in the eluent $n$ hexane-ethyl acetate ( 8 : 2), 0.05; 0.12; 0.23; 0.3; 0.81; and 0.96 for the $n$-hexane-ethyl acetate (6:4) eluent. Chloroform-methanol (9.5:0.5) yellow spots appear at a Rf value of 0.91 .

The determination of total ash content aims to determine the internal and external mineral content contained in the sample. The results showed that the total ash of $G$. forbesii leaves simplicia met the requirements. The amount of total ash content of a material indicates the high content of metal elements in the material so that the material should have a small ash content. The determination of acid-insoluble ash content aims to determine the specific amount of contamination from sand or silicate soil obtained from external factors and carried in the sample of the G. forbesii leaves simplicia. Based on the results obtained, the G. forbesii leaves simplicia contain external contamination with small levels and still meet the requirements. The contamination of impurities such as soil and sand, silver metal elements, lead, and mercury during processing can cause high insoluble acid ash in a sample (Handayani et al., 2018; Muchtadi \& Ayustaningwarno, 2010; Ratnani et al., 2017).

The determination of drying losses aims to provide a limit or range of the amount of water and volatile compounds lost during the drying process. The drying process's quality is getting better if the value of drying shrinkage is getting smaller. The results of drying losses on the simplicia obtained have met the requirements (Ministry of Health of the Republic of Indonesia, 2017). The determination of water-soluble extracts aims to determine compounds that can be found in water solvents. The compounds dissolved in water are polar. This data can be used as a reference for herbal medicine in the form of stew (infuse). The compounds dissolved in water are polar compounds such as amino acids, some vitamins, enzymes, sugars, glycosides, inorganic salts, carotenoids, proteins, saponins, tannins, and alkaloid salts (Ali et al., 2018; Hardiana et al., 2012).

The determination of ethanol-soluble extracts aims to provide an initial picture of the number of compounds found in the ethanol solvents. The ethanol solvents can dissolve the semi-polar and the polar compounds. The compounds dissolved in the ethanol are glycosides, essential oils, alkaloids, small amounts of fatty oils, pigments (chlorophyll and carotene), phenols, terpenoids, steroids, waxes, and resins (Zhang et al., 2018). The value of ethanol-soluble extracts can be used to make extracts used as a natural medicine and an initial 
description of the magnitude of compounds found in organic solvents (Handayani et al., 2018). The determination of non-specific parameters is presented in Table II.

Table II. The test results for the non-specific parameters of simplicia of G. forbesii leaves

\begin{tabular}{cccccc}
\hline Replication & $\begin{array}{c}\text { Total } \\
\text { ash } \\
\text { content } \\
(\%)\end{array}$ & $\begin{array}{c}\text { Acid } \\
\text { insoluble } \\
\text { ash } \\
\text { content } \\
(\%)\end{array}$ & $\begin{array}{c}\text { Shrinkage } \\
\text { of drying } \\
(\%)\end{array}$ & $\begin{array}{c}\text { Water } \\
\text { soluble } \\
\text { extract } \\
(\%)\end{array}$ & $\begin{array}{c}\text { Ethanol } \\
\text { soluble } \\
\text { extract } \\
(\%)\end{array}$ \\
\hline 1 & 6.47 & 0.97 & 6.6 & 34.3 & 23.5 \\
2 & 6.47 & 1.1 & 6 & 34.6 & 23.8 \\
3 & 6.63 & 1.1 & 6.7 & 34 & 23.1 \\
\hline Average \pm & $6.52 \pm$ & $1.06 \pm$ & $6.43 \pm$ & $34.3 \pm$ & $23.47 \pm$ \\
SD & 0.1 & 0.08 & 0.38 & 0.3 & 0.35 \\
Requirement & $\leq 16.6$ & $\leq 2$ & $\leq 10$ & $\geq 16$ & $\geq 8$ \\
\hline (Ministry of Health of the Republic of Indonesia, 2017; Ministry of Health \\
of the Republic of Indonesia, 1995)
\end{tabular}

\section{Determination of antioxidant activity}

The maximum wavelength is determined to determine the wavelength of the compound that provides maximum absorbance. A measurement carried out at maximum wavelength will give linear results, high instrument sensitivity, and reduce measurement errors (McBirney et al., 2016). The maximum wavelength obtained in this study is $516 \mathrm{~nm}$.

The time needed for the reaction between a compound and another compound to reach a stable point is called operating time. The operating time in determining antioxidant activity can indicate that DPPH has reacted correctly with antioxidant compounds (Salamah \& Widyasari, 2015). The operating time obtained in this study is 22 minutes.

The $\mathrm{IC}_{50}$ value determination of the antioxidant activity was performed using positive comparison quercetin. Based on these comparisons, can be seen the amount of antioxidant activity on the sample. The linear regression analysis results between quercetin concentration and the percentage of inhibition obtained using SPSS obtained the equation $y=9.634 x+12.606$ with a relation coefficient (r) of 0.998. Quercetin has an IC 50 value obtained equal to
$3.88 \mathrm{ppm}$ and classified as a very strong antioxidant activity.

The $\mathrm{IC}_{50}$ value determination of the G. forbesii leaves ethanol extract was obtained from the regression equation between the relationship of the G. forbesii leaves ethanol extract concentration with \% inhibition that was $y$ $=0.449 x+20.483$ with relation coefficient $(r)$ of 0.998 . The $\mathrm{IC}_{50}$ value of the $G$. forbesii leaves ethanol extract obtained based on the results of linear regression analysis using SPSS was $65.7 \mathrm{ppm}$ and classified as having a strong antioxidant activity. The results of measuring antioxidant activity are presented in Table III.

Table III. The antioxidants of quercetin and ethanol extract of G. forbesii leaves

\begin{tabular}{lccc}
\hline \multicolumn{1}{c}{ Samples } & $\begin{array}{c}\text { Concentrations } \\
\text { (ppm) }\end{array}$ & $\begin{array}{c}\text { Inhibition } \\
\text { (\%) }\end{array}$ & $\begin{array}{c}\text { IC }_{50} \\
\text { (ppm) }\end{array}$ \\
\hline Quercetin & 2 & 30.93 & 3.88 \\
& 3 & 43.29 & \\
& 4 & 50.41 & \\
& 5 & 60.67 & \\
The ethanol extract of & 6 & 70.41 & \\
G. forbesii leaves & 30 & 33.82 & 65.7 \\
& 50 & 42.4 & \\
& 70 & 52.49 & \\
& 90 & 61.98 & \\
& 110 & 68.97 & \\
\hline
\end{tabular}

The chemical content responsible for the antioxidant activity of G. forbesii leaves from the results of phytochemical screening is alkaloids, flavonoids, tannins, steroids, and phenols. Research conducted by Muthia et al. (2019) showed that the extracts of ethanol $30 \%$ and $70 \%$ for G. forbesii rind had $\mathrm{IC}_{50}$ values of 717.01 and $534.69 \mathrm{ppm}$, respectively. They also reported that the ethyl acetate fraction of $G$. forbesii rind had an $\mathrm{IC}_{50}$ value of $72.386 \mathrm{ppm}$ (Muthia et al., 2018). This result shows that the antioxidant activity of G. forbesii leaves is more significant than its rind.

\section{CONCLUSION}

The pharmacognostic study results of G. forbesii simplicia leaves are green, sour taste, and have a characteristic odor. The structure microscopically of the leaves can be 
seen, such as stomata, upper epidermis, lower epidermis, cell walls, xylem, phloem, palisade tissue, spongy tissue, and cuticles. The G. forbesii leaves contain positive alkaloids, flavonoids, phenols, tannins, and steroids. The TLC profile showed good separation in non-polar eluents, and yellow spots were appearing after being sprayed with DPPH reagents. The nonspecific parameters performed on G. forbesii leaves simplicia fulfill the requirements. The G. forbesii leaves ethanol extract has a strong antioxidant activity with an $\mathrm{IC}_{50}$ value of $65.74 \mathrm{ppm}$.

\section{ACKNOWLEDGMENT}

We want to express our gratitude to Universitas Lambung Mangkurat and Badan Penelitian dan Pengembangan Kebun Raya Banua Kalimantan Selatan in terms of funding and sampling of plants and all parties who assisted in the completion of our research.

\section{REFERENCES}

Alen, Y., Safitri, N., Dachriyanus, Ali, A.M., Ladjis, N.H., \& Sargent, M.V. (2008). Rubraxhantone dari Garcinia forbesii king. dan Bioaktivitasnya. Jurnal Riset Kimia, 1(2), 192-201. doi:10.25077/jrk.v1i2.76

Ali, S., Khan, M.R., Irfanullah, Sajid, M., \& Zahra, Z. (2018). Phytochemical investigation and antimicrobial appraisal of Parrotiopsis jacquemontiana (Decne) Rehder. BMC Complementary Medicine and Therapies, 18, 43. doi:10.1186/s12906-018-2114-z

Altemimi, A., Lakhssassi, N., Baharlouei, A., Watson, D.G., \& Lightfoot, D.A. (2017). Phytochemicals: Extraction, Isolation, and Identification of Bioactive Compounds from Plant Extracts. Plants, 6(4), 42. doi:10.3390/plants6040042

Andarini, F., Yasni, S., \& Syamsir, E. (2018). Pengembangan Minuman Fungsional Dari Ekstrak Kulit Mundar. Jurnal Teknologi dan Industri Pangan, 29(1), 49-57. doi:10.6066/jtip.2018.29.1.49
Dewi, A.R. (2018). Penetapan Kadar Fenol Dan Tanin Total Serta Uji Aktivitas Antioksidan Metode Frap Pada Ekstrak Etanol Kulit Buah Mundar (Garcinia forbesii King.). Undergraduate Thesis. Banjarbaru, Indonesia: Universitas Lambung Mangkurat.

Hadadi, Z., Nematzadeh, G.A., \& Ghahari, S. (2020). A study on the antioxidant and antimicrobial activities in the chloroformic and methanolic extracts of 6 important medicinal plants collected from North of Iran. BMC Chemistry, 14(1), 33. doi:10.1186/s13065-020-00683-5

Handayani, P.A., Ramadani, N.S., \& Kartika, D. (2018). Pemungutan tanin propagul mangrove (rhizopora mucronata) dengan pelarut etanol dan aquades sebagai zat warna alami menggunakan metode microwave assisted extraction. Jurnal Kompetensi Teknik, 10(1), 2227. doi:10.15294/jkomtek.v10i1.17366

Hardiana, R., Rudiyansyah, \& Anita, T. (2012). Aktivitas Antioksidan Senyawa Golongan Fenol Dari Beberapa Jenis Tumbuhan Famili Malvaceae. E-Jurnal Kimia Khatulistiwa, 1(1), 8-13.

Kabera, J.N., Semana, E., Mussa, A.R., \& He, X. (2014). Plant Secondary Metabolites: Biosynthesis, Classification, Function and Pharmacological Properties. Journal of Pharmacy and Pharmacology, 2(7), 377-392.

Kedare, S.B. \& Singh, R.P. (2011). Genesis and development of DPPH method of antioxidant assay. Journal of Food Science and Technology, 48(4), 412-422. doi:10.1007/s13197-011-0251-1

Larasati, F. (2017). Uji Aktivitas Antibakteri Fraksi Dan Senyawa Aktif Daun Seburo (Garcinia forbesii King.) terhadap Escherichia coli ATCC 25922 dan Staphylococcus aureus ATCC 25923. Undergraduate Thesis. Palembang, Indonesia: Universitas Sriwijaya.

Lim, T.K. (2012). Garcinia forbesii. In: Edible Medicinal and Non-Medicinal Plants. Dordrecht, Netherlands: Springer. doi:10.1007/978-94-007-1764-0_6

McBirney, S.E., Trinh, K., Wong-Beringer, A., \& Armani, A.M. (2016). Wavelength-normalized spectroscopic analysis of Staphylococcus aureus and Pseudomonas aeruginosa growth rates. Biomedical Optics Express, 7(10), 40344042. doi:10.1364/BOE.7.004034 
Ministry of Health of the Republic of Indonesia. (2017). Farmakope Herbal Indonesia Edisi II. Jakarta, Indonesia: Directorate General of Pharmaceutical and Medical Devices, Ministry of Health, Republic of Indonesia.

Ministry of Health of the Republic of Indonesia. (1995). Materia Medika Indonesia Jilid VI. Jakarta, Indonesia: Ministry of Health, Republic of Indonesia.

Muchtadi, T.R. \& Ayustaningwarno, F. (2010). Teknologi Proses Pengolahan Pangan. Bandung, Indonesia: Alfabeta.

Muthia, R., Saputri, R., \& Verawati, S.A. (2019). Uji Aktivitas Antioksidan Ekstrak Etanol Kulit Buah Mundar (Garcinia forbesii king.) Menggunakan Metode DPPH (2,2-Diphenyl1-Picrylhydrazil). Jurnal Pharmascience, 6(1), 7482. doi:10.20527/jps.v6i1.6079

Muthia, R., Saputri, R., \& Asfia, N. (2018). Uji Aktivitas Antioksidan Fraksi Etil Asetat Kulit Buah Mundar (Garcinia forbesii King) Menggunakan Metode DPPH (2,2-Difenil-1pikrilhidrazil). Borneo Journal of Pharmascientech, 2(2), 48-58.

Ratnani, R.D., Hartati, I., Anas, Y., Endah, D.P., \& Khilyati, D.D.D. (2017). Standardisasi Spesifik Dan Non Spesifik Ekstraksi Hidrotropi Andrographolid Dari Sambiloto (Andrographis paniculata). In: Prosiding Seminar Nasional Peluang Herbal Sebagai Alternatif Medicine Tahun 2015, 147-155. Semarang, Indonesia: Universitas Wahid Hasyim. doi:10.31942/jiffk.v0i0.1358

Salamah, N. \& Widyasari, E. (2015). Aktivitas Antioksidan Ekstrak Metanol Daun Kelengkeng (Euphoria longan (L) Steud.) dengan Metode Penangkapan Radikal 2,2'Difenil-1-Pikrilhidrazil. Pharmaciana: Jurnal Kefarmasian, $\quad 5(1), \quad 25-34$. doi:10.12928/pharmaciana.v5i1.2283

Sapna, S., Avinash, K., Mukul, T., \& Pathak, A.K. (2008). Pharmacognostic and phytochemical investigation of Stevia rebaudiana. Pharmacognosy Magazine, 4(13), 89-94.

Zhang, Q.W., Lin, L.G., \& Ye, W.C. (2018). Techniques for extraction and isolation of natural products: a comprehensive review. Chinese Medicine, 13, 20. doi:10.1186/s13020-018-0177-x 